\title{
РОССИЙСКИЙ ЛИБЕРАЛИЗМ ХХІ ВЕКА: ИСТОКИ КРИЗИСА, СОДЕРЖАНИЕ, ЕГО ВЛИЯНИЕ НА СОЦИАЛЬНО-ЭКОНОМИЧЕСКИЕ ПРОЦЕССЫ В РОССИИ
}

\author{
(C) 2019 Наумов Александр Сергеевич \\ кандидат экономических наук, старший научный сотрудник \\ Институт экономики РАН, Россия, Москва \\ E-mail: as.naumov@mail.ru
}

Рассматривается своеобразие российских либеральных устремлений, роль в них существенной части современной российской элиты, неприятие населением современных реалий, сдерживающих развитие страны (радикальный либерализм, либеральный консерватизм), несоответствие ресурсов ресурсной базе современного экономического развития, кризис либерализма в трудах зарубежных и современных исследователей, поиски выхода.

Ключевые слова: либерализм, российская элита, либеральный консерватизм, кризис либерализма, ресурсы, ресурсная база, после либерализма.

Главное своеобразие установления либеральных отношений в России - это нарушение исторических причинно-следственных связей. Либерализм на Западе явился следствием развития капиталистических отношений, а не причиной его возникновения, как в России. И поэтому он не нашел объективного понимания у населения России, большинство которого тогда составляло крестьянство. Его продвижение как с начала XX в., так и в аналогичный период XXI в. шло «сверху». Сказался привычный парадокс русского исторического развития: «носителем либеральной программы стала не общественность, а бюрократия» [1, с. 265].

Кроме того, реформы и перемены осуществлялись в условиях сохранения существующей политической системы. Важнейшей целью которой было и есть упрочение этой системы, посредством ее модернизации и вписывания в меняющуюся социальную среду, следовательно, формирование социально-экономических, политических, научных и других направлений в общественном развитии России происходило в интересах правящего класса.

Исторический опыт свидетельствует, что предлагаемые варианты реформирования социально-политического устройства России, не имели под собой объективной аргументации. Ибо присущий им идеологический или политический догмат не был готов уступить место научному анализу. «Либерализм лишь одно из начал человеческой жизни, но оно не является единственным»,- писал по этому поводу Бердяев [2, с. 565].
Именно поэтому политические взгляды, не учитывающие национальные особенности развития страны, могут негативно сказаться на ее развитии. Понимать эти особенности необходимо не как возврат к прошлому, а, как пишет Касьянова: «...к норме, к естественной модели своей культуры» [3].

Отсюда следует то, что либеральная демократия в России не была реализована должным образом. Более того, национальная буржуазия так и не стала самостоятельной общественной силой, а потому делала и до сих пор делает свои дела под крылом сильной государственной власти, а не наводит «мосты» с интеллигенцией и основной массой населения путем создания среднего класса и малого предпринимательства, что стало бы фундаментом развитого гражданского общества, скрепленного передовой интеллигенцией.

Этот процесс можно обозначить скорее как пришествие либерального консерватизма, а не развитие либеральных отношений в классическом их понимании, что было объективным явлением, так как неустойчивость существующей системы происходила от влияния на нее многообразия несопоставимых идеологических течений, развивающихся параллельно. Но парадокс российского консерватизма состоит именно в том, что вероятное переплетение этих течений политической жизни может дать положительный результат на более или менее продолжительный отрезок времени (переходный период). И тогда КОНСЕРВАТИЗМ, с приставкой ЛИБЕРАЛЬНЫЙ, не кажется таким уж не уместным. 
Более того нельзя не согласится с высказыванием по этому поводу Н. Бердяева: «...невозможно нормальное и здоровое существование и развитие общества без консервативных сил. Консерватизм поддерживает связь времен... соединяет будущее с прошлым...» [4, с. 565].

Симбиоз либеральных начал и твердой государственности сделало обращение к основам ЛИБЕРАЛЬНОГО КОНСЕРВАТИЗМА более чем актуальным, дело тут только в пропорциях, которые должны меняться в зависимости от «СОСТОЯНИЯ социально-политических и социально-экономических составляющих, что может и должно явиться катализатором возникновения новой российской государственности». [5, c. 63]

Суть российских проблем в разрыве между современностью и тенденциями исторического развития, могущих оказать решающее влияние на формирование современного общества, в затягивании либерально-консервативного периода, который из стабилизационного вполне может перейти к тормозящему.

Поэтому необходимо выделить ряд чисто российских проблем, влияющих на экономическое и социальное развитие до сих пор: во-первых, превалирование радикальных взглядов на развитие России как левого, так и правого толка; во-вторых, излишнее опекунство со стороны власти; в-третьих, носителем либеральной программы все еще является не общественность, а бюрократия; в-четвертых, главное, нарушение причинно-следственных связей, когда либерализм на Западе явился следствием развития капиталистических отношений, а не причиной, как в России, которая никак не поспевает за трансформационными процессами как в идеологическом, так и в экономическом плане. Подтверждение этому обращение к мыслителям прошлого более чем актуально.

Современно и доходчиво объяснил это Тихомиров в работе «О недостатках конституции 1906 года»,- «...задуманная и отчасти исполненная перемена Верховной власти совершена помимо требования народной воли - это не нуждается в обширных и сложных доказательствах, хотя конституция вырабатывалась и появилась под давлением заговоров, политических убийств и вооруженных восстаний, но все это не может, понятно, считаться проявлением народной воли именно на созидание того, что она совершила. Со стороны народа не было никаких ясных тре- бований, внушительных петиций и т.д. в пользу изменения Верховной власти. Выработка конституции не была совершена каким-нибудь Земским собором, а произведена в тишине канцелярий и даже втайне» [6, с. 2].

Но, если в начале XX в. (согласно ленинской теории) радикально изменить существующее положение дел могли только профессиональные революционеры, то в начале XXI в. их место должны занять научные, культурные и технические кадры. Реалии современного мира таковы: «Парадоксально, но торжество материализма будет обеспечено действием идей». [7, с. 376] Подтверждением тому является экономика, основанная на цифровых технологиях или с использованием ИИ (искусственного интеллекта). Следует отметить, что современные идеи развития экономических, технологических и политических отношений являются плодом усилий «мозговых» центров ведущих держав мира, где не последнюю роль играют выходцы из России.

В этой связи для обеспечения конкурентоспособности отечественной экономики и ее выхода, для начала, на цифровые технологии устойчивого развития на основе структурной модернизации и возрождения реального сектора экономики на базе инноваций, обеспечивающих переход к новой модели экономического роста, абсолютно необходимо взаимоувязать демографический, финансовый, экономический, социально-индустриальный, инфраструктурный, научно-образовательный и культурноисторический потенциал страны в единый организм, что является обязательным условием этой модернизации. Выпадение одной или нескольких составляющих не приведет к желаемому результату.

Однако на практике целостной концепции, равно как и выбора приоритетов промышленного роста, их увязки с соответствующей ресурсной базой, к настоящему моменту не существует, что делает решение этих проблем крайне затруднительной.

«Очевидно, что модель экономического роста, которая может обеспечить показатель на уровне 3\% и выше, пока еще окончательно не сформирована»,- признал министр экономического развития М.С. Орешкин,- для реализации экономического, политического, и человеческого потенциалов с целью создания социального государства необходима долгосрочная экономическая программа развития страны,- но пока ее 
нет. Речь может идти только о сценариях развития»,- продолжил он [8].

Отягощает положение и то обстоятельство, что многие западные ученые предупреждают о кризисе либерализма. Их произведения так и называются «Кризис либерализма» (Р. Рормозер - немец), «Против либерализма» (Ален де Бенуа - француз), о кризисе либерального сознания писали американец Мертон Р.К., француз Вирилио П., американец Хааг Э. С их взглядами можно ознакомится в сборнике «Кризис сознания» [9]. Они пишут о том, что будет после либерализма, а мы пытаемся еще вступить в его первую фазу, фазу накопления капитала.

Видимо стоит прислушаться к мнению ученых и противопоставить этому «кризису» экономически сильное государство, основанное на цифровых технологиях, с мощными вооруженными силами и политически стабильное внутри, где не будет места диктату чиновничества, исчезнет коррупционная составляющая и незаконное обогащение в силу своей невозможности. Это может произойти только с учетом исторических особенностей развития России.

Велика здесь роль государства, так как самые передовые технологии не по плечу даже самым предприимчивым и богатым, да и фундаментальная наука не вписывается в рыночные принципы - будущность является все же прерогативой государства.

Следует отметить и то обстоятельство, что правящий слой не всегда совпадает с элитой. Ее нельзя просто заменить, сформированная не указами и назначениями, а творчеством масс, заинтересованных в положительном результате социально-экономических и политических трансформаций, она может стать примером для остальной части общества и взять на себя ответственность за законность и незыблемость установленных демократических норм.

Одним из важнейших приоритетов является наращивание человеческого капитала по всем направлениям долгосрочного развития страны, что прямо соотносится с необходимостью структурной модернизации экономики, которая должна опираться на ресурсную базу, куда входят и соответствующие трудовые ресурсы, направленной на сохранение и приумножение человеческого капитала. Опора на знания могла бы привести к возрождению российской экономики и ускорить ее интеграцию в мировое хозяйство.
В экономике, как и в остальных науках есть фундаментальная, экспериментальная и прикладная части. Выпадение одной их частей ведет к нарушению логики созидания.

Еще академик Л.И. Абалкин обращал внимание общественности на то, что особая роль в решении этого должна быть отведена науке, ибо она выделяет главное о том, что «именно обоснованная стратегия трансформации, синтезирующая общемировые тенденции развития и генетическую природу России, должна стать основой разработки программ экономического и социального роста, его источников и приоритетов, постепенного устранения усугубляющегося раскола общества» [10, С. 76-77].

Наконец, позволим себе выделить те задачи, которые предстоит решить в ходе структурной модернизации российской экономики, а именно: социальное развитие и повышение уровня жизни, развитие гражданского общества, развитие фундаментальных институтов культуры, решение экологических проблем, рост экономики и развитие социальной сферы, создание экономического и трудового потенциала, воспитанного на новых реалиях и способного выполнить задачи исторической важности, повышение качества и эффективности управления, уход от ситуационного разрешения проблем к центрально-плановым.

Пути решения на наш взгляд таковы. Во-первых, следует признать, что решение проблем структурной модернизации только за счет инерции рынка бесперспективно. Во-вторых, необходим уход от сырьевой направленности и ее адептов - непроизводственной, распределительной и финансово- посреднической деятельности к новым инновационным факторам экономического роста - научно-технической модернизации реального сектора экономики, системное применение целевых инструментов развития (план, программа) и государственного регулирования в совокупности с развитием рыночного хозяйства. В-третьих, создание национальной плановой системы, способной реализовать полный инновационный цикл, начиная с фундаментальных исследований и прикладных НИОКР, а также освоение технических, технологических инноваций, направленных на выпуск конкурентной продукции. В-четвертых, государство должно обеспечить финансирование и привлечение источников внебюджетных средств, создать благоприятные условия для инноваци- 
онной деятельности на современном этапе развития. В-пятых, для развития трудовых ресурсов, формирования и реализации личности (жилье и работа) социальная обеспеченность, транспорт и др. развить единую социально-экономическую и территориальную структуру в России, трансформировать крупные города в агломерации с целью преодоления вышеизложенных проблем. B-шестых, трансформировать существующую систему управления, используя действенные инструменты (целеполагание, прогнозирование, стратегическое планирование, непрерывная система планирования) и государственные механизмы реализации (нормативно-правовые, финансовые, организационные) направленные на конечный результат и т.д.

Следует учитывать и то обстоятельство, что в эпоху глобализации возможны «тектонические» сдвиги, которые приводят к изменениям социальной системы, слому прежних национальных институтов и к экспорту новых. Институциональные изменения, если проводить их эффективно, создают условия для экономического роста. Эти перемены должны происходить по мере накопления научно-технического знания и человеческого «капитала», что незамедлительно затребует новых идей и идеологических установок.

Становится очевидным, что идеи должны быть направлены на создание такой ресурсной базы продвижения вперед, которая позволила бы вобрать в себя все население страны, а не только узконаправленных специалистов, наделить такую базу понятными целями и моральными ориентирами и отделить, наконец, природные РЕСУРСЫ от понятИя РЕСУРСНОЙ БАЗЫ, ибо в понятие ресурсной базы входят время, пространство, словом, все, что нас окружает, и поставить дело так, как обрисовал его американ- ский политический деятель Вильсон. На вопрос в сенатском комитете, где обсуждали его кандидатуру, чьи интересы будут более важными для будущего министра - страны или фирмы, Вильсон ответил: «Я привык считать; то, что хорошо для нашей страны, хорошо и для «Дженерал моторс, и наоборот. Это одно и то же» [11].

Для этого современной России необходимо изменить структуру национальной экономики. Здесь главным видится роль государства, только оно сможет устранить основные диспропорции в экономике и склонить к развитию интересов страны различные группы, разбогатевшие на экспорте природных богатств и блокирующие институциональные изменения, влияющие на их благополучие.

В заключение отметим, что П. Струве в своей работе «Интеллигенция и революция» дал квинтэссенцию этого процесса: «Интеллигенция нашла в народных массах лишь смутные инстинкты, которые говорили далекими голосами, сливавшимися в какой-то гул. Вместо того чтобы этот гул претворить систематической работой в сознательные членораздельные звуки национальной личности, интеллигенция прицепила к этому гулу свои короткие книжные формулы, когда гул стих, формулы повисли в воздухе», [12] - таким образом получается, что «народный дух» как бы остался в стороне от столбовой дороги развития. Между тем «сила национального единения и есть тот единственный ресурс, способный дать энергию для рывка, который положит конец нашему смутному времени»,- пишет об этой проблеме Шафаревич [13, с 628]. Однако его интеллектуальный потенциал нуждается в реализации во времени и в пространстве (патриотизм). Он не статичен. Он стареет или эмигрирует. Что остается?

\section{Библиографический список}

1. Леонтович В.В. «Развитие либерализма в России». Полиграфресурсы. М., 1995.

2. Бердяев Н.А. Философия неравенства. АСТ. М., 2002.

3. Касьянова К. О русском национальном характере.- М.: Институт национальной модели экономики, 1994.

4. Бердяев Н.А. Философия неравенства. АСТ. М., 2002.

5. Наумов Либеральный консерватизм в России: история и современность. Вестник МИМ Линк. № 3. 2014.

6. Тихомиров Л. О недостатках конституции 1906 года. М.: Университетская типография., Страстной бульв. 1907.

7. Пайпс Р. Россия при старом режиме. Захаров, М., 2004.

8. https://www.rbc.ru/economics/23/05/2019/5ce6b0d89a79471f5643772e

9. Кризис сознания: сборник работ по «философии кризиса». Алгоритм, М., 2009.

10. Абалкин Л.И. Вызовы нового века. М., ИЭ РАН, 2001. 
11. https://dic.academic.ru/dic.nsf/dic_wingwords/3499/.

12. Струве П.Б. Интеллигенция и революция» //Вехи. Сб. Статей о русской интеллигенции. М., 1909.

13. Шафаревич И. Русский вопрос. //Революция и гражданская война. Алгоритм,- М.: 2003. 